\title{
PENGARUH PERSEPSI NASABAH TENTANG TINGKAT SUKU BUNGA, PROMOSI DAN KUALITAS PELAYANAN TERHADAP MINAT MENABUNG NASABAH
}

\author{
Tri Astuti ${ }^{1}$ \\ triastuti_055@yahoo.co.id
}

\section{$\underline{\text { Rr. Indah Mustikawati }}{ }^{2}$}

\section{Fakultas Ekonomi Universitas Negeri Yogyakarta}

\begin{abstract}
ABSTRAK
Penelitian ini merupakan penelitian ex post facto yang dilakukan pada BRI Cabang Sleman. Penelitian ini bertujuan untuk: 1) mengetahui Pengaruh Persepsi Nasabah tentang Tingkat Suku Bunga terhadap Minat Menabung Nasabah, 2) mengetahui Pengaruh Persepsi Nasabah tentang Promosi terhadap Minat Menabung Nasabah, 3) mengetahui Pengaruh Persepsi Nasabah tentang Kualitas Pelayanan terhadap Minat Menabung Nasabah dan 4) mengetahui Pengaruh Persepsi Nasabah tentang Tingkat Suku Bunga, Promosi dan Kualitas Pelayanan terhadap Minat Menabung Nasabah di BRI Cabang Sleman.

Populasi dalam penelitian ini adalah seluruh nasabah penyimpan di BRI Cabang Sleman sedangkan sampel yang digunakan sebanyak 100 responden dengan teknik pengambilan sampel menggunakan metode random. Teknik pengumpulan data yang digunakan yaitu menggunakan kuisioner sedangkan teknik analisis data menggunakan analisis regresi linier berganda, uji prasyarat (uji normalitas, uji multikolinieritas, uji linearitas) dan uji statistik (uji t, uji F dan koefisien determinasi).

Hasil dari penelitian ini menunjukkan bahwa uji normalitas dengan KolmogorovSmirnov Test secara keseluruhan distribusi data bersifat normal. Untuk uji multikolinieritas diperoleh nilai tolerance lebih dari 0,1 dan VIF kurang dari 10 sehingga model regresi tidak ada masalah multikolinearitas. Dari analisis regresi diperoleh hasil: 1)Persepsi Nasabah tentang Tingkat Suku Bunga berpengaruh positif dan signifikan terhadap Minat Menabung Nasabah dengan nilai korelasi sebesar 0,406 dan t-hitung sebesar 4,394; 2)Persepsi Nasabah tentang Promosi berpengaruh positif dan signifikan terhadap Minat Menabung Nasabah dengan hasil nilai korelasi sebesar 0,571dan t-hitung sebesar 6,892; 3)Persepsi Nasabah tentang Kualitas Pelayanan berpengaruh positif dan signifikan terhadap Minat Menabung Nasabah dengan nilai korelasi 0,503 dan t-hitung 5,755; 4) secara keseluruhan Persepsi Nasabah tentang Tingkat Suku Bunga, Promosi dan Kualitas Pelayanan berpengaruh positif dan signifikan terhadap Minat Menabung Nasabah di BRI Cabang Sleman dengan F-hitung sebesar 26,374 dan R square sebesar 0,452 yang artinya variabel dependen dapat dijelaskan oleh variabel independen sebesar 45,2 \% sedangkan sisanya sebesar 54,8 \% dijelaskan oleh variabel lain diluar model regresi.
\end{abstract}

Kata kunci: Persepsi Nasabah, Tingkat Suku Bunga, Promosi, Kualitas Pelayanan, Minat Menabung

\footnotetext{
${ }^{1}$ Alumni Prodi Akuntansi Fakultas Ekonomi Universitas Negeri Yogyakarta

${ }^{2}$ Staf Pengajar Jurusan P. Akuntansi Fakultas Ekononi Universitas Negeri Yogyakarta
} 


\section{ABSTRACT}

This study is an ex post facto research conducted at the BRI branch Sleman. This study aimed to determine: 1) the effect of Customer Perceptions of Interest Rate on Saving Customer Interests, 2) the effect of Customer Perceptions of Promotion of Saving Customer Interests, 3)the effect of the Customer Perception of Service Quality for Customer Savings Interest and 4)Customer Perception influence on Interest Rate, Promotion and Quality Service to the Customer Savings Interest BRI branch in Sleman.

The population in this study were all depositors in Sleman branch of BRI while the sample of 100 respondents who used the technique of random sampling method. Data collection techniques used were using a questionnaire, while data analysis techniques using multiple linear regression analysis, prerequisite test (normality test, multicollinearity, linearity test) and statistical tests ( $t$ test, $F$ test and the coefficient of determination).

Results of this study showed that test with Kolmogorov-Smirnov normality test overall data distribution is normal. To test multicollinearity tolerance values obtained more than 0.1 and VIF less than 10 so the regression model no multicollinearity problem. Results obtained from the regression analysis: 1) Customer's Perception of Interest Rate positive and significant effect of the Interests Saving Customer with correlation value of 0.406 and $t$-count equal to 4.394; 2) Customer's Perception of Promotion positive and significant effect on the results of the Customer Savings Interest correlation value of 0.571 and t-count equal to 6.892; 3) Customer Perception of Service Quality positive and significant effect on Customer Saving Interest with a correlation value 0.503 and t-count equal to 5.755 ; 4) Customer's overall perception of the Interest Rate, Promotion and Service Quality positive and significant effect on customer interest in BRI Branch Savings Sleman with F-count equal to 26.374 and $R$ square of 0.452 which means that the dependent variable can be explained by the independent variables was $45.2 \%$ while the remaining $54.8 \%$ is explained by other variables outside regression models.

Keywords: Customer Perceptions, Interest Rate, Promotion, Service Quality, Saving Customer Interests

\section{A. PENDAhuluan}

\section{Latar Belakang Masalah}

Bank merupakan suatu lembaga keuangan yang berperan penting dalam perekonomian suatu negara. Semakin berkembang industri perbankan maka semakin baik pula pertumbuhan ekonomi negara tersebut. Bank sebagai lembaga keuangan berfungsi untuk menghimpun dan menyalurkan dana kepada masyarakat dalam rangka meningkatkan pemerataan, pertumbuhan ekonomi dan stabilitas nasional kearah peningkatan kesejahteraan rakyat banyak. Dengan demikian, bank menjadi wahana yang mampu menghimpun dan menyalurkan dana masyarakat secara efektif dan efisien kearah peningkatan taraf hidup rakyat (Sigit Triandaru dan Totok Budisantoso, 2009:10).

Sumber penghimpunan dana bank berasal dari beberapa sumber. Salah satu 
sumber dana bank yang berperan bagi kelangsungan kegiatan operasional bank adalah dana dari pihak ketiga yaitu tabungan. Sumber dana yang berasal dari pihak ketiga merupakan sumber dana yang cukup besar dan berpengaruh terhadap bank.

Pertumbuhan dunia perbankan saat ini sangat pesat. Bank-bank baru banyak bermunculan. Dengan semakin banyaknya bank-bank baru tersebut mengakibatkan persaingan antar bank menjadi semakin ketat. Persaingan yang semakin ketat ini menuntut bank untuk dapat mempertahankan maupun menarik nasabah sebanyak mungkin. Berbagai pendekatan dilakukan bank untuk memperebutkan nasabah baik melalui peningkatan sarana-prasarana, produk maupun pelayanan nasabah. Dengan berbagai fasilitas dan kemudahan yang diberikan bank, nasabah sebagai pengambil keputusan mempunyai banyak pilihan sesuai kebutuhan.

Perkembangan yang pesat dalam dunia perbankan saat ini ditandai dengan banyaknya bank-bank syariah yang bermunculan. Banyaknya bank syariah yang ada, menuntut bank konvensional untuk lebih peka terhadap kebutuhan maupun perilaku nasabah sehingga nasabah tidak akan berpindah ke bank syariah maupun bank lain. Perilaku nasabah terhadap bank dapat dipengaruhi oleh sikap dan persepsi nasabah terhadap karakteristik perbankan itu sendiri. Dalam menginterpretasikan suatu informasi, antar nasabah tidaklah sama meskipun informasi yang diterima berasal dari sumber yang sama (Kotler dan Amstrong, 2008:174). Hal ini yang menjadi salah satu tantangan tersendiri bagi bank untuk dapat menarik minat menabung nasabah.

Dalam upaya menarik minat nasabah untuk menabung di bank dilakukan berbagai upaya. Salah satunya yaitu penetapan tingkat suku bunga bank. Tingkat suku bunga yang ditetapkan bank akan berdampak terhadap perilaku nasabah bank. Bunga yang diberikan oleh bank kepada nasabah merupakan daya tarik bagi masyarakat untuk melakukan penyimpanan uangnya di bank. Dalam perbankan syariah tidak menerapkan sistem bunga tetapi sistem bagi hasil. Hal inilah yang menjadi salah satu yang membedakan antara bank syariah dengan bank konvensional. Dalam bank konvensional tingkat suku bunga yang ditetapkan diharapkan dapat menarik minat nasabah untuk menabung di bank. Namun, tingkat suku bunga yang fluktuatif menjadikan masalah tersendiri bagi bank konvensional. Ketidakstabilan suku bunga akan mempengaruhi minat nasabah untuk menabung karena nasabah sebagai pelaku dalam dunia perbankan akan lebih tertarik pada bank yang mampu memberikan balas jasa maupun nilai tambah yang lebih besar. 
Dengan tingkat suku bunga simpanan yang tinggi maka akan mendorong nasabah untuk menyimpan dananya di bank dengan harapan tingkat pengembalian yang akan diperoleh juga semakin besar tetapi sebaliknya ketika tingkat suku bunga rendah maka minat nasabah untuk menabung juga menjadi berkurang. Suku bunga yang tinggi akan mendorong investor untuk menanamkan dananya di bank daripada menginvestasikannya pada sektor produksi atau industri yang memiliki tingkat risiko lebih besar (Tajul Khalwaty, 2000 : 144). Bagi bank, semakin tinggi minat menabung nasabah berarti kepercayaan nasabah terhadap tinggi dan semakin tinggi kepercayaan nasabah pada bank maka semakin besar dana masyarakat yang bisa dihimpun sehingga akan dapat meningkatkan kemampuan bank untuk membiayai operasionalnya yang sebagian besar berupa pemberian kredit pada masyarakat.

Selain tingkat suku bunga yang ditetapkan bank, ada faktor lain yang harus diperhatikan oleh bank untuk dapat menarik minat nasabah yaitu upaya bank untuk memasarkan produknya yaitu promosi. Kegiatan promosi yang dilakukan bank menjadi sarana untuk memperkenalkan produk yang dimiliki bank kepada nasabah sehingga nasabah mengenal lebih jauh produk-produk yang ditawarkan bank. Promosi merupakan kegiatan penting bagi setiap perusahaan termasuk bank karena sebaik apapun produk yang dihasilkan jika tidak dikenal oleh nasabah maka produk tersebut tidak akan berhasil di pasaran (Indriyo, 2000:235).

Kualitas pelayanan memiliki hubungan yang erat dengan kepuasan pelanggan. Kualitas pelayanan memberikan suatu dorongan kepada pelanggan untuk menjalin ikatan/hubungan yang kuat dengan perusahaan. Dalam jangka panjang, memungkinkan perusahaan untuk memahami dengan seksama harapan pelanggan serta kebutuhan mereka. Dengan demikian, perusahaan dapat meningkatkan kepuasan pelanggan dengan memaksimumkan pengalaman pelanggan yang menyenangkan dan meminimumkan pengalaman pelanggan yang kurang menyenangkan.

Pelayanan pelanggan menjadi penting bagi bank dalam upaya memberikan kepuasan kepada nasabah sehingga nasabah tetap percaya pada bank dan meminimumkan nasabah pindah ke bank lain. Pelayanan bermutu hanya bisa dipahami dari sudut pandang nasabah sehingga bank harus merumuskan pelayanan bermutu melalui sudut pandang nasabah tersebut. Begitu juga dengan kehadiran beragam layanan perbankan di Indonesia yang berlomba-lomba memberikan pelayanan bermutu bagi setiap nasabahnya. Untuk kemajuan bank maka perlu mencermati 
permintaan nasabah terhadap suatu produk atau jasa yang akan ditawarkan, salah satunya yaitu dengan meningkatkan kualitas pelayanan. Nasabah dapat memutuskan terhadap suatu produk atau jasa, salah satunya dengan meningkatkan kualitas pelayanan ( Basu Swastha, 2001:158 ).

Berdasarkan uraian tersebut di atas, maka peneliti tertarik untuk menyusun skripsi dengan judul "Pengaruh Persepsi Nasabah Tentang Tingkat Suku Bunga, Promosi Dan Kualitas Pelayanan Terhadap Minat Menabung Nasabah (Studi Kasus di BRI Cabang Sleman)".

\section{B. KAJIAN LITERATUR}

\section{Minat Menabung Nasabah}

Minat merupakan suatu keinginan yang timbul dari diri sendiri tanpa ada paksaan dari orang lain untuk mencapai suatu tujuan tertentu. Menurut Pandji (1995:9), minat adalah rasa suka (senang) dan rasa tertarik pada suatu objek atau aktivitas tanpa ada yang menyuruh dan biasanya ada kecenderungan untuk mencari objek yang disenangi tersebut. Minat lebih dikenal sebagai keputusan pemakaian atau pembelian jasa/produk tertentu. Keputusan pembelian merupakan suatu proses pengambilan keputusan atas pembelian yang mencakup penentuan apa yang akan dibeli atau tidak melakukan pembelian dan keputusan tersebut diperoleh dari kegiatankegiatan sebelumnya yaitu kebutuhan dan dana yang dimiliki (Sofjan Assauri, 2011: 141).

Dalam dunia perbankan yang dimaksud dengan konsumen atau pelanggan adalah nasabah. Menurut undang-undang No. 10 Tahun 1998 tentang Perbankan pasal 1,"Nasabah adalah pihak yang menggunakan jasa bank sedangkan nasabah penyimpan adalah nasabah yang menempatkan dananya di bank dalam bentuk simpanan berdasarkan perjanjian bank dengan nasabah yang bersangkutan”.

Dari uraian di atas dapat disimpulkan bahwa minat menabung nasabah adalah keinginan yang datang dari diri nasabah untuk menggunakan produk/jasa bank atau melakukan penyimpanan atas uang mereka di bank dengan tujuan tertentu.

\section{Persepsi Nasabah}

Dalam bertindak seseorang dipengaruhi oleh persepsinya mengenai situasi tertentu. Menurut Kotler dan Amstrong (2008:214) , persepsi adalah proses dimana seseorang memilih, mengatur dan menginterpretasikan informasi untuk membentuk 
suatu yang berarti mengenai dunia sedangkan Tatik Suryani mendefinisikan persepsi sebagai suatu proses yang diawali oleh suatu stimuli yang mengenai indra manusia untuk kemudian dilakukan respon (Tatik Suryani, 2008:97-98).

Schiffman dan Kanuk (2004:158) mendefinisikan persepsi sebagai berikut:

"Perception is defined as the process by which an individual selects, organizes and interprets stimuli into a meaningful and coherent picture of the world".

Dari uraian di atas dapat disimpulkan bahwa persepsi nasabah merupakan proses nasabah dalam memilih, mengelola dan menginterpretasikan informasi yang diterima dan selanjutnya akan dilakukan respon atas informasi tersebut.

\section{Persepsi Nasabah tentang Tingkat Suku Bunga}

Bunga merupakan salah satu instrumen moneter yang selalu digunakan dalam berbagai kebijakan moneter konvensional yang biasanya dinyatakan dalam persentase. Menurut Rahmat dan Maya (2011:101), bunga merupakan suatu bentuk penghasilan bagi pemilik uang yang karena pengorbanannya selama waktu tertentu untuk melepaskan kesempatan untuk tidak menggunakan uang tersebut karena digunakan oleh pihak lain, sedangkan menurut Kasmir (2012:154), suku bunga merupakan balas jasa yang diberikan oleh bank berdasarkan prinsip konvensional kepada nasabah yang membeli atau menjual produknya.

Kasmir (2012:154) juga menjelaskan bahwa dalam kegiatan perbankan konvensional ada dua macam bunga yang diberikan bank kepada nasabahnya yaitu:

a. Bunga simpanan

Bunga simpanan merupakan harga beli yang harus dibayar bank kepada nasabah pemilik simpanan. Bunga simpanan ini diberikan sebagai rangsangan atau balas jasa kepada nasabah yang menyimpan uangnya di bank.

b. Bunga pinjaman

Bunga pinjaman merupakan bunga yang dibebankan kepada peminjam (debitur) atau harga jual yang harus dibayar oleh nasabah peminjam kepada bank.

Besar kecilnya suku bunga yang ditetapkan oleh suatu bank akan berpengaruh terhadap keputusan nasabah dalam menyimpan uangnya di bank. Jika tingkat suku bunga tinggi/naik maka volume tabungan di bank akan naik sedangkan pada tingkat suku bunga rendah cenderung akan mengurangi volume tabungan di bank. Hal ini dikarenakan minat nasabah untuk menabung di bank cenderung lebih tinggi ketika 
tingkat suku bunga naik dengan harapan return yang akan diterima nasabah juga akan naik (Herman Darmawi, 2006:181).

Dari penjelasan di atas dapat disimpulkan bahwa persepsi nasabah tentang tingkat suku bunga merupakan proses nasabah untuk memilih, mengelola dan menginterpretasikan informasi yang diperoleh tentang tingkat suku bunga yang berlaku di bank dan kemudian akan direspon melalui tindakan yaitu apakah akan melakukan investasi/menyimpan uang di bank atau tidak dengan tingkat suku bunga yang berlaku tersebut.

\section{Persepsi Nasabah tentang Promosi}

Menurut Sofjan Assauri (2011:264), promosi merupakan kegiatan yang dilakukan untuk mempengaruhi nasabah untuk menciptakan permintaan atas suatu produk /jasa, sedangkan menurut Rambat promosi merupakan strategi pemasaran yang dilakukan oleh bank kepada nasabah untuk menjelaskan produk-produk bank sehingga nasabah mendapatkan informasi yang jelas mengenai produk yang ditawarkan bank dan nasabah akan dapat memilih produk yang sesuai (Rambat Lupiyoadi, 2001:70).

Dari uraian di atas dapat disimpulkan bahawa persepsi nasabah tentang promosi merupakan proses nasabah untuk memilih, mengelola dan menginterpretasikan informasi yang diperoleh atas kegiatan promosi yang dilakukan bank dan kemudian akan direspon melalui tindakan yaitu ketertarikan nasabah untuk menggunakan atau tidak menggunakan produk/jasa yang ditawarkan bank.

\section{Persepsi Nasabah tentang Kualitas Pelayanan}

Kualitas pelayanan dapat diukur baik atau tidaknya berdasarkan sudut pandang nasabah bukan berdasarkan penyedia jasa. Meskipun demikian, bukan berarti kualitas pelayanan tidak dapat diukur. Persepsi terhadap kualitas pelayanan didefinisikan sebagai penilaian menyeluruh atas keunggulan suatu jasa (Fandy Tjiptono, 2000:61). Kualitas pelayanan merupakan keseluruhan ciri dan karakteristik dari suatu produk/jasa dalam memenuhi kebutuhan dan selera pelanggan/nasabah (Rambat Lupiyoadi, 2001:144).

Dengan demikian, persepsi nasabah tentang kualitas pelayanan merupakan proses nasabah untuk memilih, mengelola dan menginterpretasikan informasi yang diperoleh tentang pelayanan yang diberikan bank kepada nasabah dan kemudian akan direspon melalui tindakan. Semakin banyak komplain yang diterima bank 
menandakan bahwa kualitas pelayanan yang diberikan bank kurang memuaskan.

\section{Kerangka Berfikir}

a. Pengaruh Persepsi Nasabah tentang Tingkat Suku Bunga terhadap Minat Menabung Nasabah

Penetapan tingkat suku bunga bank sangat berperan penting terhadap kelancaran usaha bank. Suku bunga yang ditetapkan bank akan memengaruhi sikap nasabah terhadap bank. Nasabah sebagai pihak yang memanfaatkan jasa bank akan bersikap lebih cermat dalam kegiatan menginvestasikan/menyimpan dana yang dimiliki. Salah satu dasar pertimbangan nasabah dalam investasinya terkait dengan tingkat suku bunga yang diberlakukan bank. Bank dengan tingkat suku bunga tinggi akan lebih diminati oleh nasabah. Hal ini dikarenakan nasabah akan cenderung lebih memilih bank yang mampu memberikan balas jasa lebih besar atas dana yang diinvestasikan. Dengan harapan bahwa dengan balas jasa (suku bunga) yang tinggi maka tingkat pengembalian yang akan diterima nasabah juga akan menjadi besar.

b. Pengaruh Persepsi Nasabah tentang Promosi terhadap Minat Menabung Nasabah

Promosi merupakan kegiatan yang dilakukan perusahaan termasuk bank dalam memasarkan produknya. Dengan kegiatan promosi tersebut diharapkan nasabah akan mengetahui lebih jauh mengenai produk yang ditawarkan bank kepada nasabah. Berbagai sarana digunakan untuk memasarkan produknya kepada nasabah dengan tujuan agar nasabah tertarik terhadap apa yang dipromosikan bank sehingga dengan ketertarikan tersebut dapat meningkatkan kepercayaan nasabah terhadap bank dan hal ini akan berdampak pada minat nasabah untuk menggunakan produk bank semakin besar.

c. Pengaruh Persepsi Nasabah tentang Kualitas Pelayanan terhadap Minat Menabung Nasabah

Kualitas pelayanan yang dilakukan bank ikut berperan dalam memajukan usaha bank. Kualitas pelayanan yang baik akan meminimumkan keluhan nasabah terhadap bank. Kualitas pelayanan yang baik dari bank merupakan respon yang dilakukan bank terhadap keinginan maupun kebutuhan nasabah. Dengan merespon keinginan nasabah maka nasabah akan merasa lebih dihargai oleh bank sehingga minat nasabah untuk menabung di bank tersebut semakin besar. Minat Menabung Nasabah yang tinggi dapat menciptakan nasabah yang loyal sehingga peluang 
nasabah untuk pindah ke bank lain semakin kecil.

d. Pengaruh Persepsi Nasabah tentang Tingkat Suku Bunga, Promosi dan Kualitas Pelayanan terhadap Minat Menabung Nasabah

Tingkat suku bunga menjadi salah satu strategi bank untuk dapat menarik minat nasabah dalam menginvestasikan dananya di bank konvensional. Bank yang mampu menawarkan suku bunga lebih tinggi akan lebih diminati oleh nasabah. Nasabah akan lebih tertarik untuk menginvestasikan dananya di bank dengan tingkat suku bunga tinggi dengan harapan return yang tinggi.

Namun, selain tingkat suku bunga ada beberapa hal yang harus diperhatikan bank untuk dapat menarik minat nasabah. Promosi menjadi salah satu hal penting dalam upaya menarik minat nasabah. Dengan melakukan promosi atas produk-produk yang ditawarkan bank kepada nasabah maka pengetahuan/informasi yang akan diperoleh nasabah terkait produk-produk bank tersebut menjadi lebih luas. Dengan demikian nasabah akan lebih tahu banyak informasi sehingga dapat memutuskan produk yang sesuai dengan kebutuhannya. Dengan promosi yang tepat maka akan dapat menarik minat nasabah untuk menggunakan produk yang ditawarkan bank.

Selain itu, hal penting lain yang harus diperhatikan bank adalah mengenai kualitas pelayanan bank. Nasabah akan lebih senang terhadap bank yang peka terhadap kebutuhan nasabahnya. Kepekaan bank terhadap nasabah ditunjukkan dengan kualitas pelayanan yang baik kepada nasabah. Semakin baik kualitas pelayanan yang diberikan oleh bank akan meningkatkan minat nasabah untuk menabung di bank tersebut.

\section{METODE PENELITIAN}

\section{Tempat dan Waktu Penelitian}

Penelitian ini dilakukan pada BRI Cabang Sleman yang beralamat di Jl. Bhayangkara No. 18 Sleman, Yogyakarta. Adapun penelitian ini dilakukan pada bulan Januari 2013.

\section{Desain Penelitian}

Penelitian ini merupakan penelitian kausal komparatif (causal-comparative research) yang merupakan tipe penelitian dengan karakteristik masalah berupa sebab-akibat antara dua variabel atau lebih. Penelitian kausal komparatif merupakan tipe penelitian ex post facto karena penelitian ini dilakukan untuk meneliti peristiwa yang telah 
terjadi (Nur Indriantoro dan Bambang Supomo, 2009: 27). Berdasarkan jenis penelitian, penelitian ini tergolong ke dalam penelitian kuantitatif yaitu penelitian yang datanya berbentuk angka atau data kualitatif yang diangkakan (skoring). Penelitian ini menganalisis tentang Pengaruh Persepsi Nasabah tentang Tingkat Suku Bunga, Promosi dan Kualitas Pelayanan terhadap Minat Menabung Nasabah.

\section{Populasi dan Sampel Penelitian}

Populasi merupakan kumpulan pengukuran atau data pengamatan yang dilakukan terhadap orang, benda atau tempat. Sampel merupakan sebagian dari populasi. Populasi dalam penelitian ini adalah seluruh nasabah yang mempunyai simpanan di BRI Cabang Sleman sedangkan yang menjadi sampel dalam penelitian ini yaitu sejumlah nasabah BRI Cabang Sleman yang dipilih secara acak (random) untuk dijadikan sebagai responden.

\section{Teknik Pengumpulan Data}

Dalam pengumpulan data metode digunakan menggunakan kuisioner yaitu metode pengumpulan data dengan cara memberikan atau menyebarkan daftar pertanyaan kepada responden.

\section{Teknik Analisis Data}

\section{a. Uji Instrumen}

1) Uji validitas

\begin{tabular}{|l|c|c|}
\hline \multicolumn{1}{|c|}{ Variabel } & $\begin{array}{c}\text { Jumlah } \\
\text { Butir }\end{array}$ & keterangan \\
\hline Persepsi Nasabah tentang Tingkat Suku Bunga & 3 & valid \\
\hline Persepsi Nasabah tentang Promosi & 4 & Valid \\
\hline Persepsi Nasabah tentang Kualitas Pelayanan & 13 & Valid \\
\hline Minat Menabung Nasabah & 5 & valid \\
\hline
\end{tabular}

2) Uji reliabilitas

\begin{tabular}{|l|l|l|}
\hline Variabel & $\begin{array}{l}\text { Koefisien } \\
\text { alpha }\end{array}$ & keterangan \\
\hline Persepsi Nasabah tentang Tingkat Suku Bunga & 0,780 & tinggi \\
\hline Persepsi Nasabah tentang Promosi & 0,823 & Sangat tinggi \\
\hline Persepsi Nasabah tentang Kualitas Pelayanan & 0,900 & Sangat tinggi \\
\hline Minat Menabung Nasabah & 0,734 & tinggi \\
\hline
\end{tabular}




\section{b. Uji Prasyarat Analisis}

1) Uji Normalitas

Uji normalitas bertujuan untuk menguji apakah dalam model regresi, variabel pengganggu atau residual memiliki distribusi normal. Uji $t$ dan $F$ mengasumsikan bahwa nilai residual mengikuti distribusi normal. jika asumsi dilanggar maka uji statistik menjadi tidak valid atau bias terutama untuk sampel kecil.

2) Uji Linearitas

Uji linearitas digunakan untuk melihat apakah spesifikasi model yang digunakan sudah benar atau tidak. Uji linearitas digunakan untuk menghasilkan $F_{\text {hitung }}$ dari hasil perhitungan nilai $F_{\text {hitung kemudian dibandingkan }}$ dengan $\mathrm{F}_{\text {tabel. }}$ Jika $\mathrm{F}_{\text {hitung }}>\mathrm{F}_{\text {tabel }}$ maka hipotesis nol yang menyatakan bahwa spesifikasi model dalam bentuk fungsi linear ditolak.

3) Uji Multikolinearitas

Uji multikolinearitas bertujuan untuk menguji apakan model regresi ditemukan adanya korelasi antar variabel bebas. Model regresi yang baik seharusnya tidak terjadi korelasi antar variabel independen.

\section{c. Uji Hipotesis}

1) Analisis Regresi Berganda

Analisis regresi berganda merupakan regresi linear yang melibatkan dua atau lebih dari dua variabel, satu variabel terikat dan dua atau lebih varibel bebas (Iqbal Hasan, 2008:45).

2) Uji Linearitas $(F)$

Dalam uji linearitas ini digunakan untuk menguji apakah garis regresi antara $\mathrm{X}$ dan $\mathrm{Y}$ membentuk garis linear atau tidak. Jika tidak linear maka analisis regresi tidak dapat dilanjutkan.

3) Uji Parsial ( t )

Uji-t digunakan untuk menguji koefisien regresi yang digunakan untuk menentukan apakah variabel independen ( $\mathrm{X}$ ) memiliki pengaruh terhadap variabel dependen ( $\mathrm{Y}$ ).

4) Uji Koefisien Determinasi $\left(R^{2}\right)$

Koefisien determinasi (R2) pada intinya mengukur seberapa jauh kemampuan model dalam menerangkan variasi variabel independen. Nilai 
koefisien determinasi adalah antara nol dan satu. Nilai $\mathrm{R}^{2}$ yang kecil berarti kemampuan variabel-variabel independen dalam menjelaskan variasi variabel dependen sangat terbatas. Nilai yang mendekati satu berarti variabel-variabel independen memberikan hampir semua informasi yang dibutuhkan untuk memprediksi variasi variabel dependen.

\section{HASIL PENELITIAN DAN PEMBAHASAN}

\section{Hasil Analisis Data}

a. Pengaruh Persepsi Nasabah tentang Tingkat Suku Bunga terhadap Minat Menabung Nasabah

Hasil analisis data menunjukkan bahwa nilai tertinggi sebesar 12 dan nilai terendah sebesar 3. Dengan menggunakan bantuan SPSS maka diperoleh hasil yaitu Mean sebesar 7,99; Median sebesar 8,00; Modus sebesar 7,00 dan Standar Deviasi sebesar 1,839. Jumlah kelas interval yaitu $K=1+3,3 \log 100=7,6$ dibulatkan menjadi 7 . Rentang data $=12-3=9$ dan panjang kelas interval 1,285 dibulatkan 1,3. Jadi dapat disimpulkan bahwa kecenderungan variabel Persepsi Nasabah tentang Tingkat Suku Bunga dalam kategori cukup.

Berdasarkan hasil pengujian menunjukkan bahwa secara parsial variabel Persepsi Nasabah tentang Tingkat Suku Bunga $\left(\mathrm{X}_{1}\right)$ berpengaruh positif signifikan terhadap Minat Menabung Nasabah (Y) yang berarti jika Persepsi Nasabah tentang Tingkat Suku Bunga $\left(\mathrm{X}_{1}\right)$ semakin tinggi maka akan berpengaruh positif terhadap Minat Menabung Nasabah signifikan. Hal ini didukung dengan hasil yang diperoleh berupa koefisien korelasi sebesar 0,406 serta uji signifikansi parsial (uji t) yang menghasilkan nilai t-hitung sebesar 4,394.

b. Pengaruh Persepsi Nasabah tentang Promosi terhadap Minat Menabung Nasabah

Hasil analisis data menunjukkan bahwa nilai tertinggi sebesar 16 dan nilai terendah sebesar 4. Dengan menggunakan bantuan SPSS maka diperoleh hasil yaitu Mean sebesar 9,9; Median sebesar 10,0; Modus sebesar 9,0 dan Standar Deviasi sebesar 2,427. Jumlah kelas interval yaitu $K=1+3,3 \log 100=7,6$ dibulatkan menjadi 7 , rentang data $=16-4=12$ dan panjang kelas interval 1,714 dibulatkan menjadi 1,7. Jadi dapat disimpulkan bahwa kecenderungan variabel Persepsi Nasabah tentang Promosi dalam kategori cukup. 


\section{JURNAL NOMINAL / VOLUME II NOMOR I / TAHUN 2013}

Berdasarkan hasil pengujian menunjukkan bahwa secara parsial variabel Persepsi Nasabah tentang Promosi $\left(\mathrm{X}_{2}\right)$ berpengaruh positif dan signifikan terhadap Minat Menabung Nasabah (Y) yang berarti jika Persepsi Nasabah tentang Promosi $\left(\mathrm{X}_{2}\right)$ semakin tinggi maka akan berpengaruh positif dan signifikan terhadap Minat Menabung Nasabah. Hal ini didukung dengan hasil yang diperoleh berupa koefisien regresi sebesar 0,571 serta uji signifikansi parsial (uji t) yang menghasilkan nilai t-hitung sebesar 6,892.

c. Pengaruh Persepsi Nasabah tentang Kualitas Pelayanan terhadap Minat Menabung Nasabah

Hasil analisis data menunjukkan bahwa nilai tertinggi sebesar 52 dan nilai terendah sebesar 15. Dengan menggunakan bantuan SPSS maka diperoleh hasil yaitu Mean sebesar 41,76; Median sebesar 41,0; Modus sebesar 39,0 dan Standar Deviasi sebesar 6,320. Jumlah Kelas Interval $K=1+3,3 \log 100=7,6$ dibulatkan menjadi 7, rentang data $=52-15=37$ dan panjang kelas interval 5,285 dibulatkan menjadi 5,3 Jadi dapat disimpulkan bahwa kecenderungan variabel Persepsi Nasabah tentang Kualitas Pelayanan dalam kategori tinggi.

Berdasarkan hasil pengujian menunjukkan bahwa secara parsial variabel Persepsi Nasabah tentang Kualitas Pelayanan $\left(\mathrm{X}_{3}\right)$ berpengaruh positif dan signifikan terhadap Minat Menabung Nasabah (Y) yang berarti jika Persepsi Nasabah tentang Kualitas Pelayanan $\left(\mathrm{X}_{3}\right)$ semakin tinggi maka akan berpengaruh positif terhadap Minat Menabung Nasabah. Hal ini didukung dengan hasil yang diperoleh berupa koefisien korelasi sebesar 0,503 serta uji signifikansi parsial (uji t) yang menghasilkan nilai t-hitung sebesar 5,755.

d. Pengaruh Persepsi Nasabah tentang Tingkat Suku Bunga, Promosi dan Kualitas Pelayanan terhadap Minat Menabung Nasabah

Hasil analisis data menunjukkan bahwa nilai tertinggi sebesar 20 dan nilai terendah sebesar 8. Dengan menggunakan bantuan SPSS maka diperoleh hasil yaitu Mean sebesar 14,08; Median sebesar 14,0; Modus sebesar 4,0 dan Standar Deviasi sebesar 2,126. Jumlah Kelas Interval $K=1+3,3 \log 100=7,6$ dibulatkan menjadi 7 , rentang data $=20-8=12$ dan panjang kelas interval 1,714 dibulatkan menjadi 1,7. Jadi dapat disimpulkan bahwa kecenderungan variabel Minat Menabung Nasabah dalam kategori tinggi. 


\section{JURNAL NOMINAL / VOLUME II NOMOR I / TAHUN 2013}

Berdasarkan hasil pengujian secara simultan menunjukkan bahwa variabel $\left(\mathrm{X}_{2}\right.$ dan $\left.\mathrm{X}_{3}\right)$ berpengaruh positif dan signifikan terhadap Minat Menabung Nasabah (Y) yang ditandai dengan nilai t-hitung sebesar 4,513 dan 4,483. Hal ini berarti jika Persepsi Nasabah tentang Promosi dan Kualitas Pelayanan semakin tinggi maka akan berpengaruh positif dan signifikan terhadap Minat Menabung Nasabah, sedangkan variabel $\left(\mathrm{X}_{1}\right)$ berpengaruh positif tidak signifikan yang ditandai dengan nilai t-hitung sebesar 0,871.

Berdasarkan hasil uji $\mathrm{F}$ secara simultan menunjukkan bahwa secara bersama-sama Persepsi Nasabah tentang Tingkat Suku Bunga, Promosi dan Kualitas Pelayanan menunjukkan hasil yang positif dan signifikan terhadap Minat Menabung Nasabah yaitu dapat ditunjukkan dari perhitungan uji F sebesar 26,374 sedangkan nilai koefesien determinasi $\left(\mathrm{R}^{2}\right)$ sebesar 0,452 sehingga variabel independen dapat menjelaskan variable dependen sebesar 0.452 atau 45,2\% dan sisanya 54,8\% dijelaskan oleh variabel lain di luar model regresi.

\section{E. PENUTUP}

\section{Kesimpulan}

a. Persepsi Nasabah tentang Tingkat Suku Bunga berpengaruh positif signifikan terhadap Minat Menabung Nasabah. Hal ini ditunjukkan dengan nilai korelasi sebesar 0,406 dan t-hitung sebesar 4,394.

b. Persepsi Nasabah tentang Promosi berpengaruh positif dan signifikan terhadap Minat Menabung Nasabah. Hal ini didukung dengan hasil yang diperoleh berupa koefisien korelasi sebesar 0,571serta uji signifikansi parsial (uji t) yang menghasilkan nilai t-hitung sebesar 6,892 dengan t-tabel sebesar 1,980.

c. Persepsi Nasabah tentang Kualitas Pelayanan berpengaruh positif dan signifikan terhadap Minat Menabung Nasabah. Hal ini terbukti dengan hasil yang diperoleh berupa koefisien korelasi sebesar 0,503 serta uji signifikansi parsial (uji t) yang menghasilkan nilai t-hitung sebesar 5,755>1,980.

d. Persepsi Nasabah tentang Tingkat Suku Bunga, Promosi dan Kualitas Pelayanan secara bersama-sama berpengaruh positif dan signifikan terhadap Minat Menabung Nasabah di BRI Cabang Sleman. Hal ini diperoleh dari nilai t-hitung masing-masing variabel dan hasil uji $\mathrm{F}$ sebesar 26,374 serta nilai koefisien determinasi $\left(\mathrm{R}^{2}\right)$ sebesar 0,452 . 


\section{Saran}

a. BRI Cabang Sleman

1) Variabel yang mempunyai pengaruh tertinggi adalah Promosi. Oleh karena itu, kegiatan promosi yang telah dilakukan perusahaan sebaiknya terus ditingkatkan untuk dapat menarik dan meningkatkan Minat Menabung Nasabah di BRI Cabang Sleman dengan tetap memperhatikan efektivitas promosi.

2) Meskipun Promosi merupakan faktor yang paling banyak berpengaruh tetapi perusahaan juga tetap harus memperhatikan faktor lain seperti Kualitas Pelayanan yang diberikan bank kepada nasabah. Hal ini dikarenakan Kualitas Pelayanan terhadap nasabah ikut berpengaruh positif terhadap Minat Menabung Nasabah di BRI Cabang Sleman, sehingga kualitas pelayanan kepada nasabah harus lebih ditingkatkan untuk menciptakan kenyaman nasabah.

3) Untuk dapat menarik minat nasabah menabung di BRI Cabang Sleman sebaiknya perusahaan dalam menetapkan tingkat suku bunga bank juga harus mampu bersaing dengan bank lain, meskipun Tingkat Suku Bunga tidak terlalu besar pengaruhnya tapi besaran Suku Bunga ikut berpengaruh positif terhadap Minat Menabung Nasabah.

b. Penelitian Selanjutnya

Penelitian ini hanya terbatas pada Persepsi Nasabah tentang Tingkat Suku Bunga, Promosi dan Kualitas Pelayanan sehingga diharapkan bagi penelitian selanjutnya lebih diperluas mengenai faktor-faktor lain yang mempengaruhi Minat Menabung Nasabah.

\section{F. DAFTAR PUSTAKA}

Anas Sudijono. (2009). Pengantar Statistik Pendidikan. Jakarta: PT. Raja Grafindo Persada.

A.Usmara. (2003). Strategi Baru: Manajemen Pemasaran. Yogyakarta: Amara Books.

Arya Maman Putra. (2010). Analisis Pengaruh Kualitas Produk, Fasilitas, Kualitas Pelayanan dan Promosi Terhadap Loyalitas Nasabah Pada PT. BCA Cabang Kanjengan Semarang. Skripsi. Universitas Diponegoro Semarang. 
Bari'ah, Zaenal Abidin, Harlina Nurtjahjanti. (2008). Hubungan Antara Kualitas Layanan Bank Dengan Minat Menabung Nasabah Pt Bri Kantor Cabang Ungaran. Skripsi. Universitas Diponegoro Semarang.

Basu Swasta. (2001). Manajemen Penjualan. Yogyakarta: BPFE.

Buchari Alma (2004). Manajemen Pemasaran dan Pemasaran Jasa. Bandung: CV. Alfabeta.

Fandy Tjiptono. (2000). Manajemen Jasa. Yogyakarta: Andi Offset. . (2005). Service, Quality \& Satisfaction. Yogyakarta: Andi Offset

Herman Darmawi. (2006). Pasar Finansial dan Lembaga-Lembaga Finansial. Jakarta: PT. Bumi Aksara.

Husein Umar. (2008). Desain Penelitian Akuntansi Keperilakuan. Jakarta:Raja Grafindo Persada.

Imam Ghozali. (2011). Aplikasi Analisis Multivariate dengan Program IBM SPSS 19. Semarang: Badan Penerbit Universitas Diponegoro.

Indriyo Gitosudarmo. (2000). Manajemen Pemasaran edisi pertama. Yogyakarta: BPFE.

Iqbal Hasan. (2008). Analisis Data Penelitian Dengan Statistik. Jakarta: Bumi Aksara.

Kasmir. (2012). Dasar-dasar Perbankan. Jakarta: PT. Raja Grafindo Persada.

Kotler, Philip dan Gary Amstrong. (2008). Prinsip-Prinsip Pemasaran edisi 12. Jakarta: Erlangga.

Muhammad Dwi Ari Susanto. (2012). Pengaruh Produk Tabungan Dan Kualitas Pelayanan Terhadap Keputusan Menabung Pada KJKS BMT Binna Ummat Sejahtera Kec. Lasem. Skripsi. Universitas Diponegoro Semarang.

Nur Indriantoro dan Bambang Supomo. (2009). Metodologi Penelitian Bisnis Untuk Akuntansi \& Manajemen. Yogyakarta : BPFE. 
Pandji Anoraga. (1995). Dinamika Koperasi. Jakarta: Rineka Cipta.

Rachmat Firdaus dan Maya Ariyanti. (2011). Pengantar Teori Moneter serta Aplikasinya Pada Sistem Ekonomi Konvensional dan Syariah. Bandung: Alfabeta.

Rambat Lupiyoadi. (2001). Manajemen Pemasaran Jasa. Jakarta: Salemba Empat.

Schiffman, G. Leon dan Leslie Lazar Kanuk. (2004). Consumer Behavior. USA: Pearson Education Inc.

Sigit Triandaru dan Totok Budisantoso. (2009). Bank dan Lembaga Keuangan Lain. Jakarta: Salemba Empat.

Sofjan Assauri. (2011). Manajemen Pemasaran. Jakarta: Rajawali Pers.

Sugiyono. (2007). Statistika untuk Penelitian. Bandung : Alfabeta.

Tajul Khalwaty. (2000). Inflasi dan Solusinya. Jakarta: PT. Gramedia Pustaka Utama.

Tatik Suryani. (2008). Perilaku Konsumen: Implikasi Pada Strategi Pemasaran. Yogyakarta: Graha Ilmu.

Ujang Sumarwan. (2011). Perilaku Konsumen. Jakarta: PT Ghalia Indonesia.

Universitas Negeri Yogyakarta. (2007). Pedoman Penulisan Tugas Akhir Jurusan Pendidikan akuntansi. Yogyakarta : Universitas Negeri Yogyakarta.

Undang-Undang Nomor 10 Tahun 1998 Tentang Perbankan.

Zulian Yamit. (2002). Manajemen Kualitas Produk dan Jasa. Edisi Pertam Cetakan Kedua. Yogyakarta: Ekonisia.

http://www.bri.co.id/corporate 